\title{
Paleolimnological study of Lake Uchum (South Siberia, Russia)
}

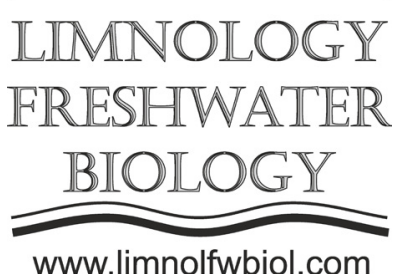

\author{
Zykov V.V.*, Bolobanshchikova G.N., Bulkhin A.O.
}

Institute of Biophysics Siberian Branch of the Russian Academy of Sciences" (IBP SB RAS) 50/50 Akademgorodok, Krasnoyarsk 660036, Russia

\begin{abstract}
In the course of this work, the bottom sediments of Lake Uchum located in the Minusinsk depression, in the south part of the Krasnoyarsky kray were studied. The subjects of the investigation were the photosynthetic pigments, alkenones, and valves of diatoms extracted from the core of bottom sediments. We discovered the presence of characteristic photopigments of green algae, and, in addition to them, the okenon of a carotenoid specific to purple sulfur bacteria, as indicator of meromixia. The presence of okenon in the bottom sediments of the lake is irregular, which likely indicates the instability of the lake hydrological regime in the past. Alkenones in the lake bottom sediments demonstrate a dependence on the physicochemical conditions of the lake water. The found diatom frustules were often strongly decayed and belong to the same species along the core. However, inclusions of wellpreserved frustules were also found, which were most likely reworked.
\end{abstract}

Keywords: HPLC, Paleolimnology, paleoproxies, pigment analysis, diatom analysis, alkenones

\section{Introduction}

Meromictic lakes are the archives of the various proxies that can provide a valuable data about lake past (Boehrer \& Schultze, 2008). Lakes Shira and Uchum are one of well-studied meromictic lakes in South Siberia (Rogozin et al., 2018). Bottom sediment of these meromictic lakes have undisturbed thin-layer structure that allow to reconstruct the paleo-history of the lake and region. Among the paleo-proxies a most vide used are the studies of fossil photopigments, diatom shells and alkenones. Photopigments are usually connected to the definite group of phototrophs and allow to compare they diversity and production in the past (Bianchi, Canuel, 2011).

The shape of diatom frustules allows to determine its species, also diatom is very sensitive to environmental condition, therefore analysis of fossil shells may reconstruct changes in the lake ecosystem (Flower, Ryves, 2009).

Alkenones are the long-chain hydrocarbons that produces only by several species of Haptophyta algae. They ration of factions with different quantity of double-bond correspond with environmental condition such as temperature and salinity. Its wildly used for reconstruction of paleotemperature for the oceans, and it also can be used for inland waterbodies (Randlett et al., 2014; Radle, et al, 1989).

Research of the paleo proxies of bottom sediments from Lake Uchum may provide data for further understanding of the past of ecosystem of Minusinsk depression.

\section{Materials and methods}

Lake Uchum (55.05.670 N, 89.43.390 E) is a meromictic lake is located in the North Minusinsk depression, $30 \mathrm{~km}$ south of the city of Uzhur, on the territory of the Uzhursky District of the Krasnoyarsky kray. Its reservoir has an oval shape of $1.5 \times 4 \mathrm{~km}$ with a surface area of about $4 \mathrm{~km}^{2}$ and a maximum depth of $7.9 \mathrm{~m}$ (2015). The ionic composition of water is sulfate-chloride, sodium-potassium (Krivosheev et al, 1990). The salinity in the upper layers of mixolimnion during the summer stratification in 2015 and 2016 was about $24 \mathrm{~g} \mathrm{l}^{-1}$ and $34 \mathrm{~g} \mathrm{l}^{-1}$ in the bottom layers. Bottom sediments of the lake have a mostly undisturbed layered structure, which makes the reservoir a valuable object for conducting paleo-study.

In this work, the core of the bottom sediments of Lake Uchum, sampled in the summer of 2015, was studied. This core was analyzed for the pigment composition, diatom frustules and long-chain hydrocarbons - alkenones.

Extraction and analysis of photosynthetic pigments was performed by the modified method of Wright et al. (1991), which was also used in studies of Lake Shira.

*Corresponding author.

E-mail address: zykovvv@yandex.ru (V.V. Zykov)

(C) Author(s) 2020. This work is distributed under the Creative Commons Attribution 4.0 License. 
Diatom frustules analysis was performed by standard method (Bolobanshchikova, et al., 2018) and identified with reference book.

Alkenone study was performed by the method described Randlett et al (Randlett, et al., 2014). Analysis was carried out by the GH-MS chromatograph Agilent 7890/5975C. Identification of peaks was made according to, the data from Jaraula et al. ( 2010)

\section{Results and discussion}

Chromatographic analysis of photopigments extracted from bottom sediments revealed that they contain several main carotenoids originated from different group of algae. Among them are alloxanthin (Cryptophyta), Loraxanthin (green algae), Lutein (green algae), zeaxanthin (Cyanobacteria) and the carotenoid of purple sulfur bacteria - okenone. Pigment composition of the bottom sediments shown below (Fig. 1) indicates that the lake underwent significant changes throughout the formation of the core, which affected its phototrophic communities. The dynamics of okenone, paleoproxy of the presence of hydrogen sulfide in the bottom layers of the lake, varies from 15 to $450 \mathrm{mkg} \mathrm{g}^{-1}$. In the samples from 200-270, 320350 and $460-520 \mathrm{~cm}$, the concentration of okenone reaches the minimum values (approx. $1-3 \mathrm{mkg} \mathrm{g}^{-1}$ ) and in the area 720-790 disappears completely. This likely indicates a weakening of the hydrogen sulfide zone in the monimolimnion of the lake during that period (Overmann, 2008). Carotenoids of green sulfur bacteria (chlorobactene and isorenieratene) are absent in all samples of the core, which is presumably caused by unfavorable conditions for them.

Alkenones were discovered in bottom sediments of Lake Uchum in sufficient amounts. Based on the data obtained by gas chromatography, the unsaturation indices of the alkenone fractions Uk37, Uk'37, Uk38 and Uk3738 were calculated. The indices Uk37 and Uk'37 (reverse index Uk37) are changing according to the temperature increase in the last century. The indices Uk38 and Uk 3738 do not show any dependence on temperature, but instead show a controversial reaction to changes in salinity (lake level) (Bianchi,Canuel, 2011).

The species composition of diatoms found in the core turned out to be extremely poor. Diatoms were mostly found singly frustules, some of which cannot be identified even to the genus due to its decayed. This indicates unfavorable conditions for the preservation of diatoms. Diatoms are distributed unevenly. Thus, samples from $36 \mathrm{~cm}$ up to $44 \mathrm{~cm}$ are characterized by sharp increases in numbers Epithemia sp., Nitzschia $s p$., Surirella $s p$. (benthic, widespread in both fresh and salt bodies of water). Cyclotella choctawhatcheeana (planktonic, brackish-water, widespread species) was found at a depth of 41-42 cm. In addition, Lindavia radiosa (planktonic, freshwater, alpine and subalpine species) and Staurosira sp. (benthic, widespread in both fresh and salt bodies of water) also were wellpreserved. The small amount of these frustules with their localization in separate layers likely evidences that they were reworked.

Obtained data suggest that lake underwent significant changes in water level during sedimentation of the sediments. The time span of the changes are closely corresponded with ones inferred from records of Lake Shira (Zykov, et al., 2012). This makes Lake Uchum a valuable object for future paleoclimate study of the region of South Siberia.

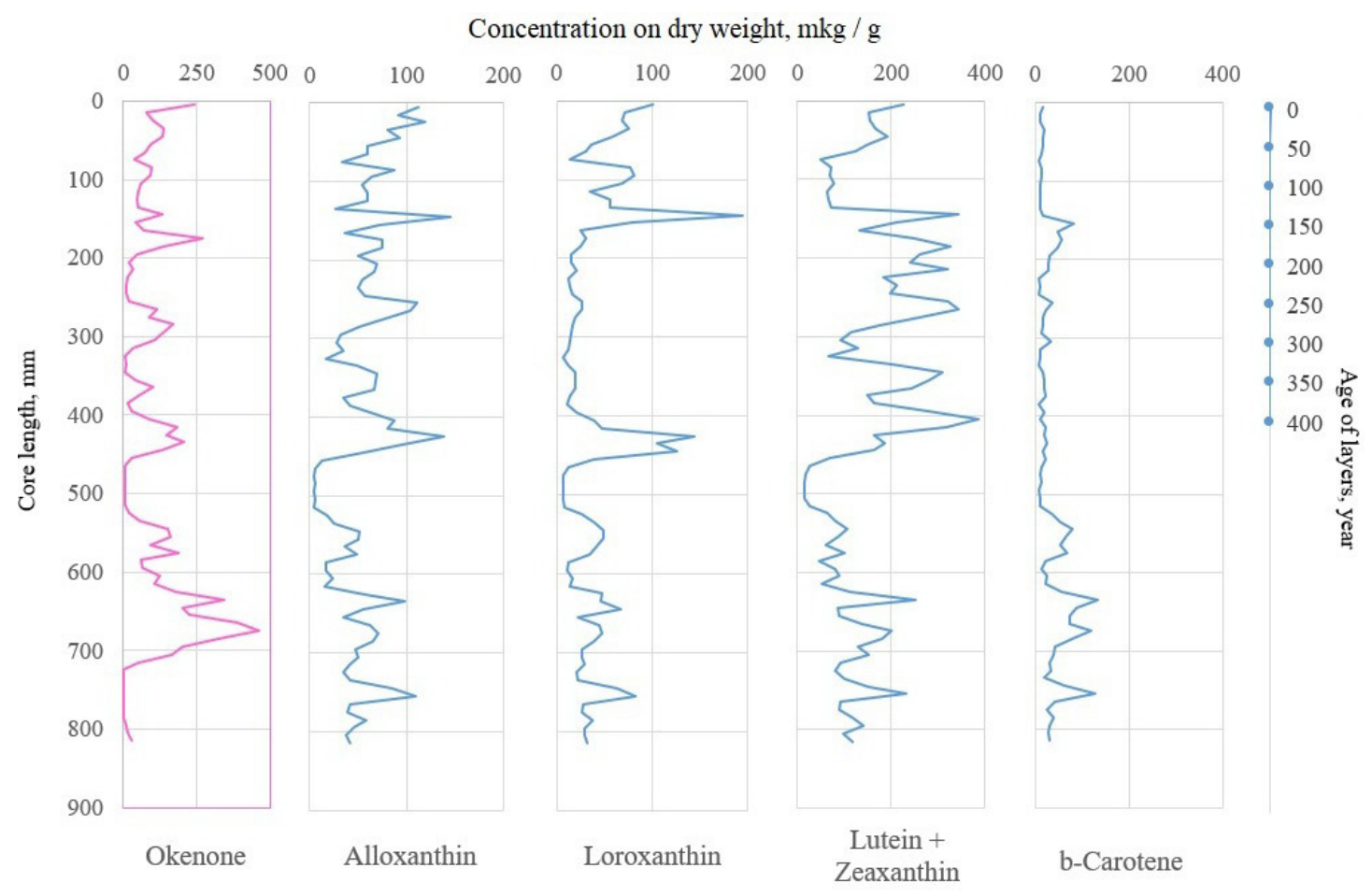

Fig.1. Distribution of carotenoids in the core of bottom sediments of Lake Uchum 


\section{Acknowledgements}

The reported study was funded by Russian Foundation for Basic Research, Government of Krasnoyarsk Territory, Krasnoyarsk Regional Fund of Science to the research project: «Bottom sediments of Lake Uchum (Krasnoyarsky kray) as a source of information for the reconstruction of the paleo-climate and the prediction of the healing properties of the lake», № 18-45-243002

\section{References}

Bianchi Thomas s. and Canuel Elizabeth A. 2011. Chemical Biomarkers in Aquatic Ecosystems [Book]. USA, Princeton, New Jersey : Published by Princeton University Press.

Boehrer B and Schultze M. 2008. Stratification of Lakes. Reviews of Geophysics. 46.

Bolobanshchikova G. N., Kulikovskiy M. S. and Rogozin D. Y. 2018. Diatoms in the Bottom Sediments of Two Closely Located Lakes in Khakassia . Journal of Siberian Federal University. Biology. 4 (11): 321-332.

Flower R.J., Ryves D.B. 2009. Diatom preservation: differential preservation of sedimentary diatoms in two saline lakes. Acta Bot. Croat. 2 (68): 381-399.
Jaraula C.M.B., Brassell S.C., Morgan-Kiss R.M et al. 2010. Origin and tentative identification of tri to pentaunsaturated ketones in sediments from Lake Fryxell. East Antarctica. Org. Geochem. 41: 386-397. https://doi.org/10.1016/j. orggeochem.2009.12.004

Krivoesheev A. S. i Khasanov A. P. 1990. Lechebnye ozera Krasnoyarskogo kraya. Krasnoyarsk : [b.n.] (in Russian).

Overmann J. 2008. Ecology of Phototrophic Sulfur Bacteria. In: Sulfur Metabolism in Phototrophic Organisms. Hell Rüdiger and et al. (Ed.).

Radle N. Keister, C. M. Battarbee R.W. 1989. Diatom, pollen, and geochemical evidence for the palaeosalinity of Medicine Lake, S. Dakota, during the Late Wisconsin and early Holocene. Journal of Paleolimnilogy. 2: 159-172.

Randlett M. et al. 2014. Alkenone distribution in Lake Van sediment over the last 270 ka: influence of temperature and haptophyte species composition. Quaternary Science Reviews. 104: 53-62.

Rogozin D. Y. et al. 2018. Meromixis and Seasonal Dynamics of Vertical Structure of Lake Uchum (South Siberia). Contemporary Problems of Ecology. 2(11): 195-206.

Wright S. W. et al. 1991. Improved HPLC method for the analysis of chlorophylls and carotenoids from marine phytolankton. Marine ecology progress series: 183-196.

Zykov V. V. et al. 2012. Carotenoids in bottom sediments of Lake Shira as a paleoindicator. Contemporary Problems of Ecology. 4(5): 434-442. 